\title{
THE USE OF LEARNING MEDIA BY JUNIOR HIGH SCHOOL TEACHERS OF SCIENCE IN TANJUNGPINANG AND BINTAN
}

\author{
Nevrita \\ nevrita@umrah.ac.id \\ Study Program of Biology Education FKIP Universitas Maritim Raja Ali Haji (UMRAH)
}

\begin{abstract}
Learning media is the most important part of learning. Professional teachers should be able to choose and use learning media. This study aims to identify the use of learning media by science teachers in Tanjungpinang and Bintan and constraints faced by teachers regarding the use of learning media. The population is all science teachers of SMP Negeri in Tanjungpinang and Bintan while the sample in this study consists of eight Junior High Schools located in Tanjungpinang and four Junior High Schools in Bintan. Sampling technique in this research is simple random sampling. While type of research is descriptive. Data collection was obtained through questionnaires, interviews and documentation. Questionnaire contains ten questions using a Guttman scale consisting of "yes" and "no" questions. Data collection is also done by interviewing teachers to find out the constraints found by teachers during the learning process takes place. Other data collection techniques are done by looking at the RPP created by teachers on the learning media used. The results obtained an average of $69.16 \%$ of teachers use learning media during the learning process took place. The results from the questionnaires obtained data about the constraints found in the teacher's use or to use the learning media. The results obtained by analyzing the RPP turns out that teachers write the media used in each meeting, this is not in accordance with the fact of the average outcomes. There should be a policy from government and school to overcome these obstacles. Further research that I suggest is to know the creativity of teachers in making learning media.
\end{abstract}

Keywords: learning media; use; descriptive; obstacles.

\section{INTRODUCTION}

Implementation of the education process in the classroom cannot be separated from the role of teachers as educators. Teachers should prepare the learning process very well and well planned. The presence of teachers in the classroom is really with the preparation and not just standing in front of the class. Teachers are required professionally in preparing the learning process. The learning process begins with the teacher's ability to make lessons plan. The ability of teachers to plan lessons should be appreciated absolutely as possible. Teachers must plan their learning with careful thought and preparation. The lesson planning that teachers must think and analyze with the brilliance of thought is in determining the media to be used at every classroom meeting. Many opinions that explain the meaning of learning media as the following opinion which states the learning media is everything 
related with facilities and infrastructure (tools / objects) are used to support or to facilitate the delivery of subjects in the learning process to achieve the goals of learning itself (asf, 2016 ). So the media is a very important learning tool during the learning process takes place, so that the learning objectives stated in the RPP can be achieved. This is also in line with other opinions stated that the media that can be utilized by teachers in accordance with the purpose of learning, while the use of media depends on the type and characteristics of a media, then how to use it should not be a teacher, but students either, as long as can achieve the purpose of teaching (Djamarah and Zain, 2012). The media might not be available only in schools but teachers are creative to think of other alternative media as a substitute for unavailable media. Teachers do not have to give up due to media limitations in schools but should strive to keep providing learning media at every meeting conducted. How importance of the media in learning as stated by Riyana (2012) "teachers should make the media as an integral part of the overall learning in school". Good learning never ignores the media in every teacher's face-to-face in the classroom. There are a lot of type of media can be used and depends on the sharpness and ability of teachers to choose and determine the appropriate type of media in learning. Learning media should be used by all teachers for all levels of education without exception as well as for IPA teachers for Junior High School level.

IPA Subjects in Junior High School cannot be separated from the use of media during the learning process. The IPA teachers of SMP must be careful and skillful in choosing the right media for learning. The subject matter of science is the material that is directly related to the real object so that the learning must be contextual and the learning objectives can be achieved. The science teachers of SMP must be able to use appropriate learning media in their learning. As Sardiman, et al (2009) says, the use of instructional media in the teaching and learning process is very important yet the role of teachers as learning agents is more important, because teachers are the prime mover that facilitates the process of teaching and learning in the classroom. Based on the above opinion is very clear that teacher plays an important role as a facilitator in learning. In selecting learning media, the teacher should pay attention to the important matters in accordance with Arsyad's (2002) opinion that "Teachers can at least use varied media, easy and efficient, although simple but a necessity in the effort to convey expected learning objectives". This is in line with the following opinion that the use of learning media can improve teachers' competence in teaching, teachers become more adept at conditioning the subject matter so that it becomes more easily transferred to students (Arnis, 2017).

The success of the learning process is determined by the ability of teachers in choosing learning media. So is the case with science teachers in Junior High School in Riau Islands Province, specifically in Tanjungpinang and Bintan. Based on the results of initial interviews conducted to IPA teachers of Junior High School in both areas found the problem that teachers do not use the media in every meeting in the classroom because there is a science material that does not require media in learning. Other problems faced by teachers are objected and reluctant to use the media because it is caused by the inability to master the technology and also due to their limitations in finding new information as learning materials that can be developed into learning media. Based on the above problems, the purpose of this study in addition to know the real condition about the use of learning media by science teachers of 
SMP in Tanjungpinang and Bintan, also to know the constraints faced by teachers with the use of learning media.

\section{METHOD}

The population of this study are all teachers of science from 12 Junior High Schools in Tanjungpinang and Bintan which simple sampling random technique. Simple random sampling is sampling technique done randomly without considering strata in the population, this technique is done when homogeneous population (Hanif and Himawanto, 2017). Twelve selected schools consist of eight Junior High Schools in Tanjungpinang and four Junior High Schools in Bintan. Data collection was obtained through questionnaires, interviews and documentation. Questionnaire contains ten questions by using a Guttman scale consisting of "yes" and "no" question. Guttman scale can be made in the form of question, multiple choice, and filled in the form tick if the answer is positive like agree, true, yes, ever and so on and give score 1, while for negative answer also given score 0 (zero) (Djaali \& Muljono, 2008). Data collection is also done by interviewing teachers to find out the constraints found by them during the learning process. Other data collection techniques are done by looking at the RPP created by teachers on the learning media used.

The data obtained will be described, but it cannot be generalized because the data obtained only from the samples studied only. This technique is a descriptive statistical analysis. Descriptive statistics obtained will be the researcher shows the form of tables, averages and percentages and followed by a description of each data.

\section{RESULTS AND DISCUSSION}

Results and discussion of research obtained can be divided into two parts, namely the use of learning media by teachers and constraints faced by them in the use of learning media. Questionnaires distributed to teachers contained ten questions as outlined in table 1 below.

Table 1. Percentage of Junior High School teachers' answers in Tanjungpinang and Bintan

\begin{tabular}{llcc}
\hline No & \multicolumn{1}{c}{ Question } & Yes & No \\
\hline 1. & Do you use the media in every lesson? & $58 \%$ & $42 \%$ \\
\hline 2 & Do you encounter obstacles in applying the media? & $58 \%$ & $42 \%$ \\
\hline 3. Have you integrated technology in learning media & $92 \%$ & $8 \%$ \\
\hline 4. $\quad \begin{array}{l}\text { Do you encounter obstacles in applying technology in } \\
\text { learning media }\end{array}$ & $58 \%$ & $42 \%$ \\
\hline 5. & $\begin{array}{l}\text { Does the use of media you apply can generate student interest } \\
\text { / motivation? }\end{array}$ & $83 \%$ & $17 \%$ \\
\hline 6. Is it necessary to conduct (media use training) to improve the & $92 \%$ & $8 \%$ \\
\hline
\end{tabular}




\begin{tabular}{llll}
\hline 7. & Is it necessary to use instructional media in every meeting? & $50 \%$ & $50 \%$ \\
\hline 8. & Can you use a variety of media available in the laboratory? & $75 \%$ & $25 \%$ \\
\hline $\begin{array}{l}\text { 9. Do you feel that the students are already using the laboratory } \\
\text { tools properly? }\end{array}$ & $67 \%$ & $33 \%$ \\
\hline $\begin{array}{l}\text { Is there any media already available in your school but cannot } \\
\text { you use it until now? }\end{array}$ & $67 \%$ & $33 \%$ \\
\hline
\end{tabular}

Based on the results obtained from table 1 above, $92 \%$ of respondent has integrated technology into learning media and it has the highest percentage of some other questions. These results show that most teachers have integrated technology in their learning. Similarly, the question of the need for training for teachers also reaches $92 \%$, essentially teachers feel it is very necessary to be given training and also other activities about the use of learning media. Due to some teachers feel the lack of training on learning media organized by both the government as well as the school. For the question of learning media can arouse the spirit or motivation of student learning is also obtained a good percentage of $83 \%$. From the results obtained for the question referred to the teacher feels very great motivation to learn students when teachers use the media in learning in the classroom. Furthermore about the utilization of media available in laboratory only $75 \%$ of teachers who use it, while $25 \%$ of teachers did not utilize the media available in the laboratory.

For questions about media usage, media usage constraints, and obstacles in integrating technology in learning media gain the result of 58\%. From the results obtained it is seen that in the learning process not all teachers use the media in learning. Teachers still ignore the use of media, while teachers should use the media in learning. The question of media usage is directly proportional to the obstacles that teachers found in using media because of the constraints that cause teachers have not used the media in their learning. Similarly, the discovery of obstacles in the integration of technology in the learning media but this question contradicts the previous question about applying technology in learning media that the percentage reached the highest number. So in filling the two questions that actually have a relationship and the relevance of answers given by teachers can be said opposite inversely proportional.

The results obtained for student questions using laboratory tools properly at $67 \%$, so not all students can use laboratory well. For questions about the use of available media but cannot be used also obtained as much as $67 \%$, it shows not all teachers can use the media available. So the demanding question of the need for training on media usage is a very urgent activity to be undertaken. While the use of media in each meeting is only partially applied. The answer required from the questions are all teachers who use the media in every classroom meeting. If examined from the questions given to teachers of science in Junior High Schools in both Tanjungpinang and Bintan then there is no answer of all that match the expectations of professional teachers because only four questions that can be considered good and as expected while six more questions still need special attention.

Results and discussion still using media usage can be explained and described in table 2 below. 
Table 2. Percentage identification of use of learning media by science teachers of SMP

\begin{tabular}{cccccc} 
No & Sampling & Percentage (\%) & No & Sampling & Persentage (\%) \\
\hline 1. & A & $\mathbf{6 0 \%}$ & $\mathbf{7 .}$ & G & $\mathbf{3 0 \%}$ \\
\hline 2. & B & $\mathbf{3 0 \%}$ & $\mathbf{8 .}$ & H & $\mathbf{7 0 \%}$ \\
\hline 3. & C & $\mathbf{9 0 \%}$ & $\mathbf{9 .}$ & I & $\mathbf{9 0 \%}$ \\
\hline 4. & D & $\mathbf{7 0 \%}$ & $\mathbf{1 0 .}$ & J & $\mathbf{6 0 \%}$ \\
\hline 5. & E & $\mathbf{8 0 \%}$ & $\mathbf{1 1 .}$ & K & $\mathbf{9 0 \%}$ \\
\hline 6. & F & $\mathbf{9 0 \%}$ & $\mathbf{1 2}$ & L & $\mathbf{7 0 \%}$ \\
\hline & & & & Average & $\mathbf{6 9 . 1 5 \%}$ \\
\hline
\end{tabular}

From the twelve samples in table 2 above can be explained the use of IPA learning media that there are two teachers rarely use the media with the percentage of achievement is only $30 \%$. The highest percentage in media usage was also obtained from four samples with a percentage of $90 \%$. So from the average obtained for the use of learning media for IPA teachers for Junior High School in Tanjungpinang and Bintan is $69.15 \%$. When interpreted then this condition describes the percentage is in good interpretation. So it can be concluded that SMP science teachers in Tanjungpinang and Bintan have used the media well. Nevertheless, there is still a need for improvement for questions that have not been able to reach a high percentage.

Based on the interviews conducted on the teacher then obtained various obstacles faced by teachers in using learning media in the learning process. These constraints can be described as follows.

\section{Limitations of learning media}

Learning media available in schools is still very limited and insufficient if used in learning, especially laboratory equipment. One of them is the number of projectors is still very limited. Projector availability for some schools where research done cannot be fulfilled for each class, so to use the projector as a learning medium needs to queue with other teachers. Another limitation is that many learning media that have been damaged cannot be functioned again but have not received a replacement

2. Availability of electricity and internet network

Some schools in Tanjungpinang and Bintan have various constraints, there are schools that have electricity but do not have internet network, there are also schools that have both facilities but the internet network is slow. With the availability of both facilities are also a very crucial constraint for teachers because they need of both facilities as the completeness of the learning media that will be taught. With the availability of the internet networking teachers can look for various materials that will be taught in the classroom.

3. Inability to use learning media

Not all respondent teachers in this research have the same ability in using learning media, especially the use of computers. It is also influenced by teacher age factor. There are some 
old teachers who are not able to use computer technology in classroom learning such as operating laptops to create PowerPoint media and also for other media-related technologies. For example, the instructional media available in the school are in the form CDs whose operations are certainly using laptops. So the inability of teachers to use learning media also need to get attention and quick handling for parties associated with this problem.

\section{Limited time in using learning media}

Another thing that also affects teachers in using learning media is time constraints. Based on the results of interviews with teachers are still reluctant to use the media in learning is due to the fear of teachers will be limited time of learning so that learning objectives are not achieved. Whereas teachers should not need to give reasons for time constraints but teachers must be able to address and manage the utilization of time in learning so that learning media can be used and learning objectives will be achieved.

Even more concerning with the reason of the limited time is a teacher who rarely takes his/her students to do activities in the laboratory. Whereas the demands of the education is currently in line with the 2013 curriculum that is not only the cognitive aspect is a priority but other aspects such as affective and psychomotor must be implemented by teachers in the classroom. One way that teachers can do that psychomotor aspects can be held in the learning is to perform activities in laboratory experiment. If the teacher never takes the student to the laboratory how can he/she fulfils the psychomotor aspect in his learning. It is okay for the teacher not to do the exploiting activity but the teacher should think about other activities that can fulfil the psychomotor aspect.

5 . Learning media is not accompanied by guidance book.

There are some media that its guidance has been lost so there are some media that can not be used by teachers because of ignorance how to use it. Most of the media available in the laboratory is so old that it has no tutorial guide. Guided learning media also obtained from government assistance for laboratory equipment is usually equipped with guidance, but the reality in the field some of the available media no longer tutorial. This is an obstacle felt by teachers in using learning media

\section{Budget constraints}

Budget constraints are also a huge obstacle in the use of instructional media. Teachers claimed that many of these media were obtained by schools from governmental aid that were not routinely distributed to a school so that not all schools got the same media at the same time. Even if one school has media and media is damaged then there are obstacles in repairing the media. This is because there is no budget available to improve or maintain the learning media. So because of that teachers do not use the media in learning. Teachers should still be able to use the media in their learning because a teacher must have high competence and innovation, so the lack of funds does not become an obstacle. This is also in line with the opinion of Muspawi and Mulyono (2014) who stated that the existence of the media should not all be dependent on the existence of funds, but also the creative effort of a teacher to innovate in addressing the problem of learning media.

Some obstacles that researcher gets from the results of research also have similarities obtained by other researchers namely Suwarno, et al (2016) which states obstacles in 
utilizing the media, among others, age factor, expensive media costs, limited facilities owned by schools, the number of students who are too big in the classroom, never given training in the use of computer media, unable to use the computer, not all teachers have a capable background in computer use.

When viewed from several obstacles obtained in this study then there are some things that need to be understood by the teacher. If a learning media does not exist because it is damaged or because of other reasons then the teacher should be professional not only hope with the availability of media but how teachers should be able to create a simple media for learning in the classroom. From some teachers who were asked not all schools found obstacles in the use of media, from twelve teachers interviewed there are teachers in one school who during the learning did not find obstacles in the use of media this is because the school has enough media for the learning process in the classroom. If there is media that is not available then the teacher makes a simple media for the learning process can be done properly. At least one teacher can display simple media in the form of PowerPoint or student worksheets in the class

The results of the analysis of teacher-made RPP found that in all RPP teachers have incorporated learning media in its RPP. This is not appropriate from the questionnaire results on questions that ask whether the teacher uses the media in each meeting and the results obtained that only some teachers who use the learning media. And this is different from the results of the researcher's analysis of RPP. This needs further study on this in the future. Because it should be written in the RPP should be in sync with the results of the questionnaire.

\section{CONCLUSIONS AND SUGGESTIONS}

\section{A. Conclusion}

1. $69,15 \%$ of science Teachers of Junior High School in Tanjungpinang and Bintan have used learning media in the learning process, although there are still some obstacles in using learning media

2. Teacher constraints in using learning media in the classroom include media limitations, availability of power lines, limited power grid and internet, inability to use media, limited time and lack of guides using media.

3. Science Teachers of Junior High School in Tanjungpinang and Bintan really need and expect training on learning media, because not all teachers have the ability and knowledge about learning media

4. Learning planning in the form of RPP made by teacher which not yet according to real implementation in front of class.

B. Suggestions

1. The government and schools must immediately address the constraints faced by science teachers in Tanjungpinang and Bintan in using media.

2. Government and schools are expected to program and plan trainings on instructional media so that understanding and knowledge of science teachers of SMP on media of learning can be improved. 
3. The principal needs to conduct a more intensive evaluation and supervision of instructional tools made by the teacher.

For other researchers need further research on the creativity of science teachers in SMP in making learning media.

\section{BIBLIOGRAPHY}

Arnis. (2017). "Penggunaan Media Pembelajaran Bervariatif Untuk Meningkatkan Kompetensi Mengajar Guru Di SDN 113 Pekanbaru”. Suara Guru : Jurnal Ilmu Pendidikan Sosial, sains, dan Humaniora Vol. 3 No. 2, Juni 2017,

Arsyad, Azhar. (2008). Media Pembelajaran. Jakarta, Raja Grafindo Persada.

Cepi Riyana. (2012). Media Pembelajaran . Jakarta, Dirjen Pendidikan Islam Kementerian Agama RI.

Djaali \& Muljono, Pudji. (2008). Pengukuran dalam Bidang Pendidikan. Jakarta, PPs UNJ.

Djamarah, S.B. dan Zain A. (2012). Strategi Belajar Mengajar. Jakarta, Rineka Cipta Hanief, Yulingga N., \& Himawanto, W. (2017). Statistik Pendidikan, Yokyakarta: Deepublish.

Mohamad Muspawi dan Maryono. (2014). "Kreatifitas Guru Dalam Menggunakan Media Pembelajaran ( Studi Kreatifitas Guru di SD No.67/ VII/ Pulau Aro I Kecamatan Pelawan Kabupaten Sarolangun )". Jurnal Penelitian Universitas Jambi Seri Humaniora Volume 15, Nomor 2, Hal. 91-94 ISSN:0852-8349 Januari - Juli 2014

Sardiman, Arief. (2009). Media Pendidikan. Jakarta, Rajawali Pers

Soewarno, Hasmiana dan Faiza. (2016). Kendala-Kendala Yang Dihadapi Guru Dalam Memanfaatkan Media Berbasis Komputer Di SD Negeri 10 Banda Aceh Pendidikan Guru Sekolah Dasar (PGSD). Jurnal Pesona Dasar Universitas Syiah Kuala Vol. 2 No.4, April 2016, hal 28 -39 ISSN: 2337-9227, 